\title{
DETERMINATION OF NUCLEAR POWER PLANT SITE IN WEST BANGKA BASED ON ROCK MASS RATING AND GEOLOGICAL STRENGTH INDEX
}

\author{
Irvani, Wahyu Wilopo, and Dwikorita Karnawati \\ Department of Geological Engineering, Gadjah Mada University, Yogyakarta, Indonesia
}

\begin{abstract}
Indonesian government through the National Atomic Energy Agency has planned to build a nuclear power plant. One of the proposed sites is in West Bangka Regency, Bangka Belitung Archipelago Province. The engineering geology of this area is, however, not fully understood and requires further investigations. Engineering geology investigations were carried out by assessing the rock mass quality and bearing capacity based on field observation and drilling data. The assessment was conducted using Rock Mass Rating (RMR) and Geological Strength Index (GSI) classifications. The rock masses in the study area were divided into four units, namely units of sandstone, granite, mudstone and pebbly sandstone. The RMR and GSI values in the study area were influenced by the parameters of discontinuity space density, the slope of discontinuity orientation, grade of weathering and groundwater conditions. The assessment shows that the granite unit had the best quality which was shown by a 53 average RMR value and 66 GSI value. Based on the average RMR value, the granite unit was estimated to have cohesion value between 0.2 and $0.3 \mathrm{MPa}$, friction angle between $25^{\circ}$ and $35^{\circ}$, and allowable bearing pressure between 280 and $135 \mathrm{~T} / \mathrm{m}^{2}$. Based on the GSI value, the granite unit was estimated to have uniaxial compressive strength value between 1.0465 and $183.8 \mathrm{MPa}$, ten-
\end{abstract}

${ }^{*}$ Corresponding author: IRVANI, Department of Geological Engineering, Gadjah Mada University. Jl. Grafika 2 Yogyakarta, Indonesia. E-mail: irvani@ubb.ac.id sile strength between (-0.0122) and (-5.2625) MPa, rock mass strength values between 24.5244 and $220.351 \mathrm{MPa}$, and modulus of deformation within a range of 1.73 - $86.68 \mathrm{GPa}$. The Granite Unit was considered to be the most appropriate location for the nuclear power plants.

Keywords: nuclear power plant foundation, Geological Strength Index, Rock Mass Rating, rock mass quality

\section{Introduction}

Construction of Nuclear Power Plant is a way to overcome the limitation of electrical energy in Indonesia. A feasibility study of nuclear power plant site was conducted in Muntok District, West Bangka Regency, Bangka Belitung Archipelago Province (Figure 1). The feasibility study invloved comprehensive investigation of the rock mechanical properties.

Bangka Island is located in the Sunda Shelf (Van Bemmelen, 1970), at the Sundaland Craton (Barber et al., 2005). Sunda Shelf is a combination of some terrane that amalgamated with Asia (Van Gorsel, 2012). The regional geology of Bangka Island show that the Complex Pemali rocks formed in the Perm time as the oldest rocks.Subsequently, it was deposited Tanjung Genting Formation rocks in Early Triassic, Granite Klabat intrusion in Late Triassic Late Jurrasic, and Ranggam Formation in Late Miocene - Early Pleistocene (Margono et al., 1995; Mangga and Djamal, 1994). 


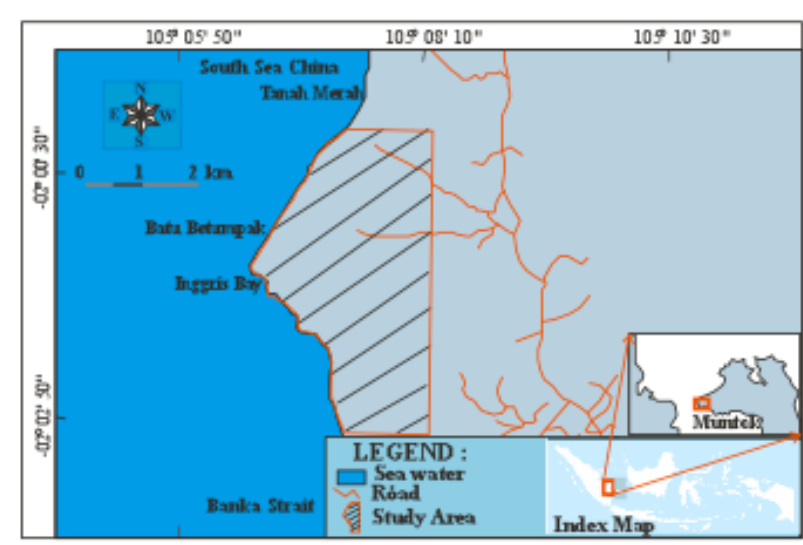

Figure 1: Study area map.

Wyllie and Mah (2004) and Giani (1992) state that rock material experienced a collapse as the rock mass. Rocks mass consists of blocks of rock and discontinuities as a union (Palmstrom, 1995). Each type of rock has different character and mechanics ability (Goodman, 1989). Analyses of rock mechanics require a model and geological data based on rock type, discontinuities structure and material properties (Hoek, 2007). Geological data collection stages are reference study, reconnaissance, drilling exploration, trenching and pitting, in situ testing, detail testing and mapping (Cheng and Lau, 2008). A comprehensive investigation of rock discontinuities is described in detail in Wyllie (1999).

This study aims to evaluate the rock mass quality for estimating the bearing capacity and determination of the best location of the shallow foundation of a nuclear power plant usingthe Rock Mass Rating (RMR) (Bieniawski, 1989) and Geological Strength Index (GSI) Classifications (Hoek, 1994).

\section{Research Methods}

This study was conducted by determining the Rock Mass Rating (RMR) (Bieniawski, 1989) and the Geological Strength Index (GSI) Methods (Hoek, 1994), from outcrop and drill core data. Uniaxial compressive strength (UCS) of rock samples were obtained from rebound values conversion of digital Schmidt hammer type $\mathrm{N}$ using Kilic and Teymen equation (Kilic and Teymen, 2008), while the adjustment value of discontinuity orientation on RMR classification was obtained using IS 12070 standard (IS12070). Based on RMR value, the values of rock cohesion and internal friction angle were estimated. Rock allowable bearing pressure was estimated using Mehrota scheme (Singh and Goel, 2011). The rock mass strength and modulus of deformation were calculated using GSI Method (Hoek et al., 2002).

\section{Results and Discussion}

Detailed geological conditions of the study area have been described by Irvani et al. (2013) and Irvani (2013). Geomorphological units in the study area were flat, gently sloping, sloping, and moderately steep hill geomorphology units. The lithologies from the youngest to the oldest were Triassic sandstone, Late Triassic - Jurasic granite, Late Miocene - Pleistocene mudstone and pebbly sandstone

\subsection{Discontinuity orientation}

Stereographic analyses using a Dips v.5.1 software were performed to determine the relative orientation of discontinuities in each rock unit (Figure 2), except the pebbly sandstone unit. Rose diagrams shown in Figure 2 indicate that the sandstone unit has a major northwestsoutheast $\left(\mathrm{N} 305^{\circ} \mathrm{E}\right)$ and northeast-southwest $\left(\mathrm{N} 25^{\circ} \mathrm{E}\right)$ principle orientations, the granite unit has a north-south $\left(\mathrm{N} 05^{\circ} \mathrm{E}\right)$ and northwestsoutheast $\left(\mathrm{N} 305^{\circ} \mathrm{E}\right)$ principle orientations, whereas the mudstone unit has north-south $\left(\mathrm{N} 05^{\circ} \mathrm{E}\right)$ and east-west $\left(\mathrm{N} 275^{\circ} \mathrm{E}\right)$ principle orientations. In general, the relative orientations of the rock discontinuities were northwestsoutheast and north-south. The faults in the study area were estimated to be old inactive faults.

\subsection{Engineering geology of the study area}

Based on the engineering geological map and cross sections from Irvani et al. (2013) and Irvani (2013) in Figure 3 and 4 , the sandstone unit occupied an area of 8.8 hectares was slightly moderately weathered, altered, compact, very strong jointed, and based on Schmidt hammer 


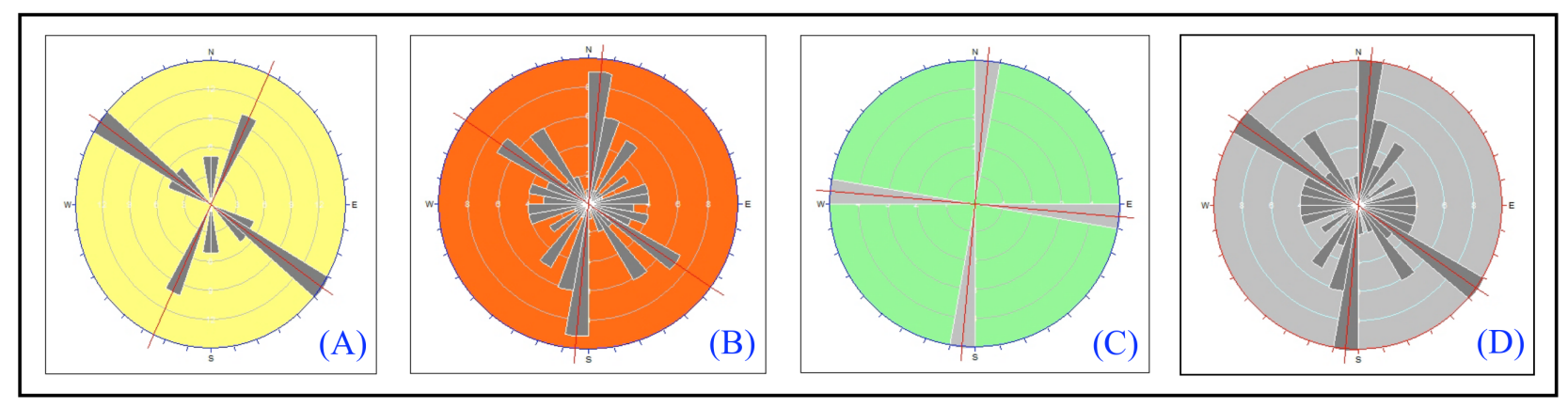

Figure 2: Principle Discontinuity orientation: (A) Sandstone, (B) Granite, (C) Mudstone, (D) All unit of rock.

rebound value, had UCS ranging from 143.25 to $241.99 \mathrm{MPa}$. The granite unit occupied an area of 393 hectares was crystalline, fresh - moderately weathered, very compact, jointed, and had UCS between 252.14 and 289.71 MPa. Mudstone unit occupied an area of 236.2 hectares and pebbly sandstone unit occupied an area of 87 hectares were moderately weathered, uncompacted well, and had a 2.93 MPa UCS. The pebbly - muddy coarse sand unit occupied an area of 469 hectares and the fine - coarse sand unit occupied an area of 41.8 hectares covered the granite and sandstone units, had a thickness of a few meters to over 80 meters, wascompact to slightly loose, and estimated as the result of rock weathering and alteration.

\subsection{Rock mass quality classification based on RMR}

Observations of 30 surface data and 20 drilling points were conducted for the rock mass quality evaluation. The engineering geological map was used to determine the distribution, depth and boundary of the RMR.

The sandstone unit has limited surface data in 3 observation stations. The basic RMR value was 53.75-62 andcorrected RMR was 31.25-42 that indicate poor to medium quality. The subsurface data of sandstones recorded at $\mathrm{BBH}$ 13 and BBH 14 drilling points were weathered and altered, present in considerable depth and are not dominant part of the sandstone unit The sandstone unit had basic RMR values from 36.26 to 37.25 and corrected RMR values from 25.25-26.26 indicating poor quality. The rock mass quality state is affected by space den- sity and slope orientation of discontinuities, the presence of filling, degree of weathering or alteration, as well groundwater condition.

Granite Unit has a very poor - very good quality, with moderate quality in general. Surface data about 24 stations observation has basic RMR between 62.33-100, corrected RMR is 41.33 - 100, has been moderate - very good quality, with moderate quality in general. Subsurface data (drilling point of $\mathrm{BBH} 01, \mathrm{BBH}$ 01A, BBH 02, BBH 03, BBH 04, BBH 06, BBH 06A, BBH 07, BBH07A, BBH 12, BBH 12A and $\mathrm{BBH}$ 14A) have the basic RMR between 2987 , corrected RMR is $4-77$, and has very poor - good quality, with moderate general quality. The rock quality is influenced by density space and orientation of discontinuities, weathering, filling, as well groundwater condition, where the quality of surface data tends better than the subsurface data, because it has less space and fresh rock condition, as well above the groundwater table.

The number of surface data of Mudstone Unit is very limited, only one observation station, with the value of basic RMR is 50.67 , corrected RMR is 33.34 , so has poor quality. Subsurface data at four drilling points (BBH 08, BBH 09, $\mathrm{BBH} 10$ and $\mathrm{BBH} 11$ ) have a range value of basic RMR is $46.34-50.67$, corrected RMR between 29.01-33.34, with poor quality. The rock quality is affected by low compressive strength (UCS) of rock, the discontinuities slope is quite high, moderate grades of weathering, and the shallowness of the water table which is characterized by the presence of artesian wells at $\mathrm{BBH} 10$ and $\mathrm{BBH} 11$ drilling point. 


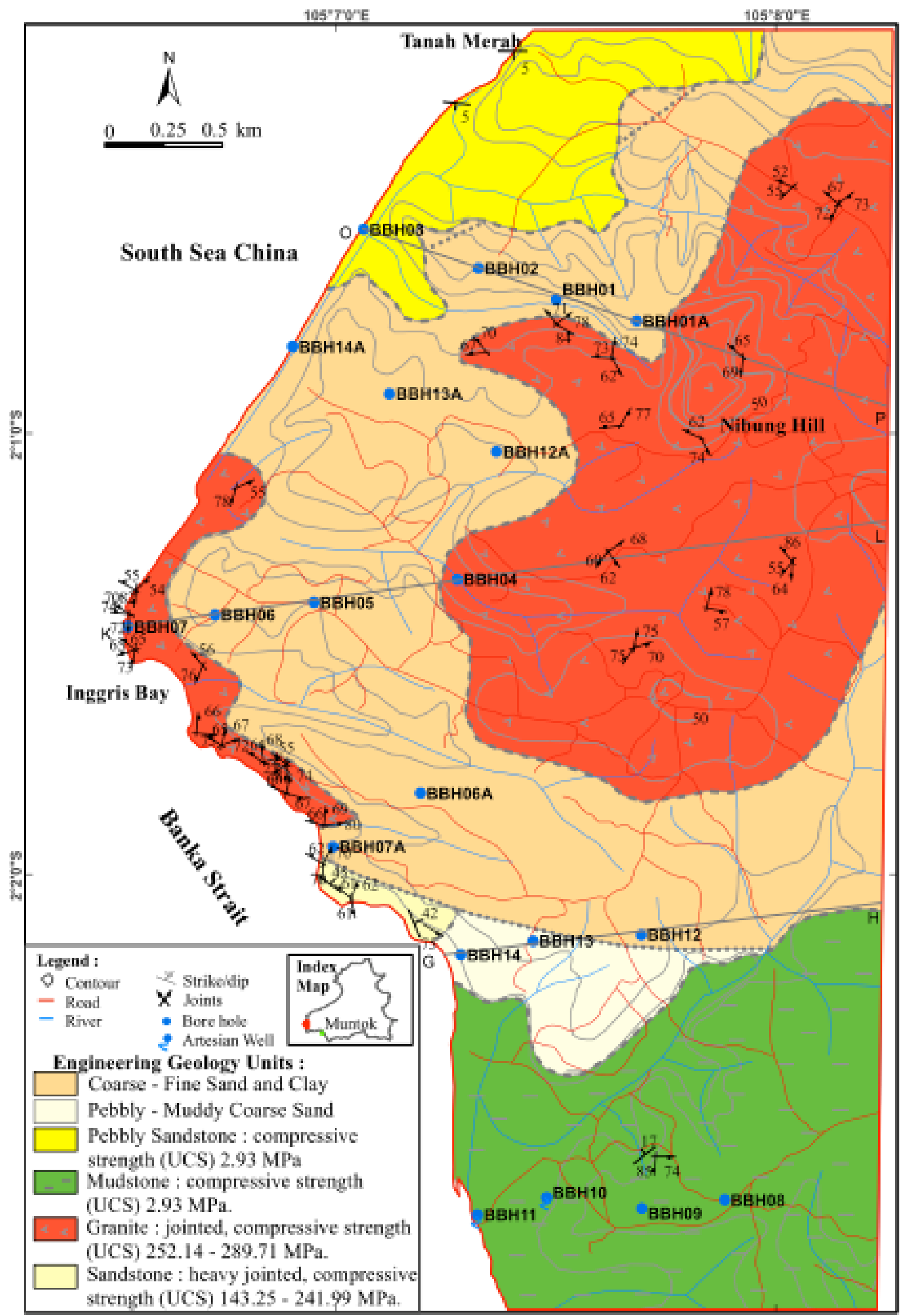

Figure 3: Engineering geological map of the study area. 
IRVANI et al.
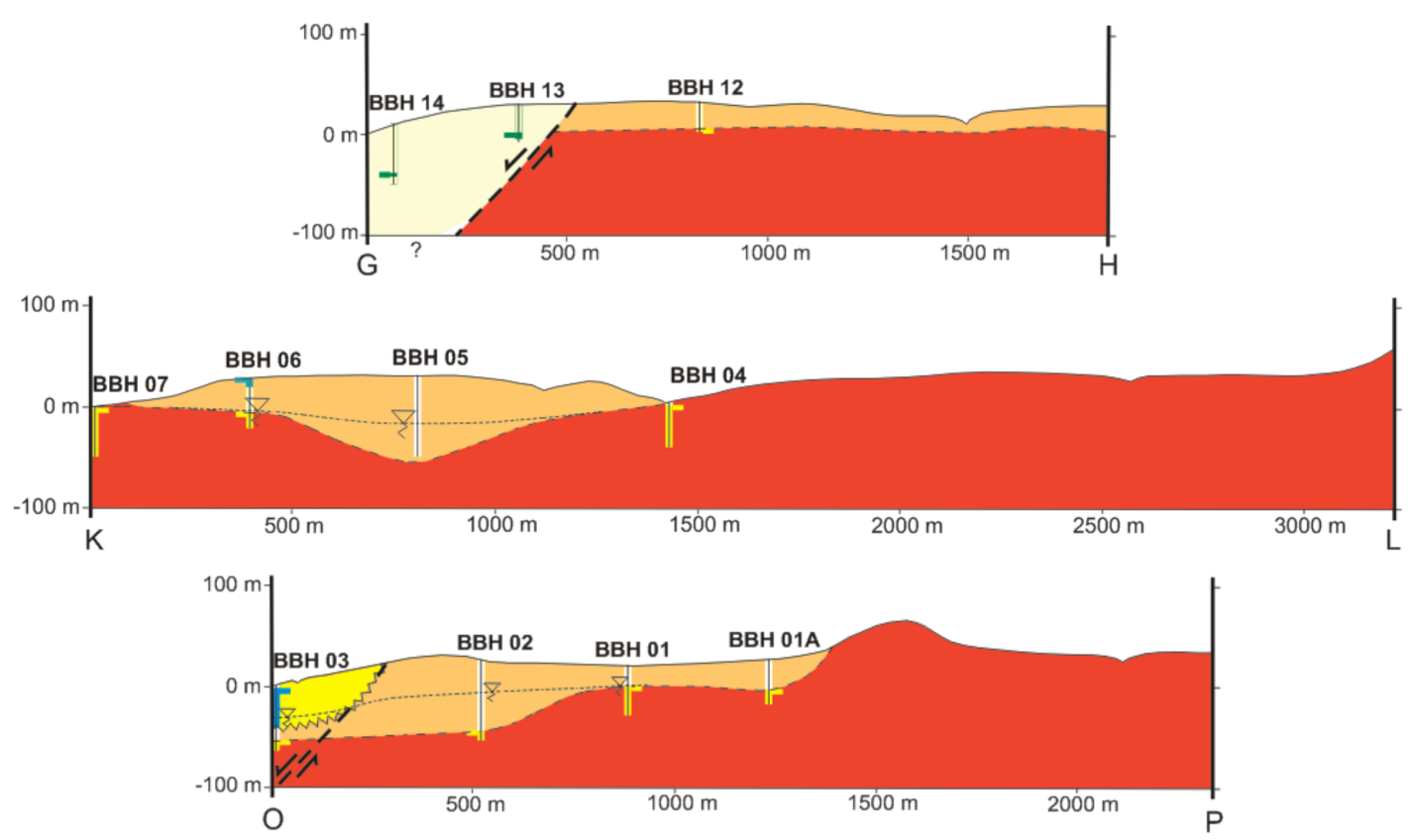

\section{Legend :}

Fine - Coarse Sand and Clay

Pebbly Sanstone

Granite

Figure 4: Engineering geological cross sections of the study area. 
Pebbly Sandstone Unit also has limited number of surface data at two station observations, has basic RMR and corrected RMR is 54, with moderate quality. Subsurface data at the BBH 03 drilling point has value of basic RMR and corrected RMR is 54, with moderate quality grade. The rock quality is influenced by the low compressive strength (UCS), and moderate weathering grade.

\subsection{Rock mass quality based on RMR classi- fication}

Based on the RMR value of rock mass, Granite and Pebbly Sandstone Unit with moderate general quality of rock mass was having estimated the range values of cohesion is $0.2-0.3 \mathrm{MPa}$, the internal friction angle between $25-35^{\circ}$, and the allowable bearing pressure is $280-135 \mathrm{~T} / \mathrm{m}^{2}$. Both of Sandstone and Mudstone Units have poor rock mass quality, has estimated value of cohesion between 0.1-0.2 $\mathrm{MPa}$, internal friction angle value is $15-25^{\circ}$, and estimated allowable bearing pressure between 135-45 T/ $\mathrm{m}^{2}$.

\subsection{Rock mass quality and capacity based on geological strength index (GSI) classifi- cation}

Rock mass GSI quality evaluation and its capacity have been discussed in detail in Irvani et al. (2013) and Irvani (2013). Variety and the best quality are owned by Granite Unit (GSI $=27-$ 95) with good general quality, whereas for the Sandstone Unit (GSI = 44-55), Mudstone Unit (GSI = 39-43) and Pebbly Sandstone Unit (GSI $=42$ ) all being moderate quality.

The result of rock capacity calculation shows the variation of value and high capacity at Granite Unit. Granite Unit has compressive strength (UCS) between 1.0465-183.8 MPa, tensile strength in a range $(-0.0122)-(-5.2625)$ $\mathrm{MPa}$, the rock mass strength between 24.5244$220.351 \mathrm{MPa}$, as well variations of modulus deformation between 1.73-86.68 GPa with an average high value. Sandstone Unit has compressive strength (UCS) between 2.3079-7.7621 $\mathrm{MPa}$, tensile strength range $(-0.2131)-(-0.0546)$ $\mathrm{MPa}$, the rock mass strength between 16.3223$33.1094 \mathrm{MPa}$, and the large of deformation

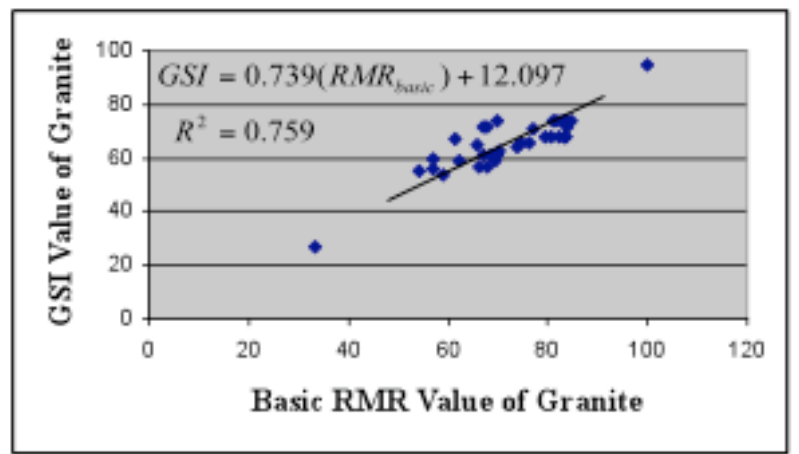

Figure 5: Linear relationship of basic RMR and GSI value of Granite Unit.

modulus between 4.60-8.67 GPa. Mudstone Unit has compressive strength (UCS) is 0.0317 $\mathrm{MPa}$, tensile strength is $-0.003 \mathrm{MPa}$, the rock mass strength is $0.1373 \mathrm{MPa}$, and modulus of deformation is $3.45 \mathrm{GPa}$. Pebbly Sandstone Unit has compressive strength (UCS) is 0.0403 $\mathrm{MPa}$, tensile strength is $-0.0009 \mathrm{MPa}$, the rock mass strength is $0.3135 \mathrm{Mpa}$, and modulus of deformation is $4.1 \mathrm{GPa}$.

\subsection{Relationship between RMR and GSI classification}

The limited amount of available data, especially for the surface data (outcrop) on Unit Sandstone, Mudstone and Pebbly Sandstone caused the results of analysis of the relationship between value of basic RMR and GSI on the third unit is not significant, significant results only showed by Granite Unit because it has rich amount of measurements data. Linear relationship basic RMR and GSI Granite Unit with regression factor is 0.759 , indicating a strong relationship and it was formulated by the equation GSI $=0.739$ (RMRbasic) +12.097 as illustrated by Figure 5 .

\subsection{The best location for nuclear power plant site}

Granite Unit is the most appropriate location for nuclear power plants site based on the quality and capacity of rocks evaluation using the RMR and GSI methods. However, not all parts of Granite Unit suitable for shallow foundation as raft foundation type, because it has thick 
weathered rock or soil layers up to tens meters like at $\mathrm{BBH} 02, \mathrm{BBH} 05, \mathrm{BBH} 12 \mathrm{~A}$, and $13 \mathrm{~A} \mathrm{BBH}$ drilling points. Rock quality assessment based on RMR method uses adjustment value of discontinuity orientation for raft foundation type, so that a thick layer of soil and weathered rock become constraints in determining the location of nuclear power plants site. Granite Unit with an area about 393 Hectares is the suitable location for shallow foundation of nuclear power plants as in Figure 6, this is in line with the opinion that raised by Irvani et al. (2013) and Irvani (2013).

\section{Conclusion}

In general, the RMR in the study area was between poor and moderate, and the GSI was between poor and good. Granite unit had the best quality from all lithological units. Granite unit was distributed over 393 Ha with a moderate RMR and a good GSI . Factors affecting the granite unit quality was the spacing density of discontinuity, filling, weathering, discontinuity orientation with respect to large slope, and groundwater flow conditions for subsurface data.

Based on the quality and bearing capacity evaluation of the rock mass using RMR and GSI classifications, the Granite unit was considered to be the most appropriate location for the placement of nuclear power plants with the raft foundation type. Based on the RMR and GSI, the estimated cohesion value of the Granite unit was $0.2-0.3 \mathrm{MPa}$, the internal friction angle was between $25^{\circ}$ and $35^{\circ}$, allowable bearing pressure wass between 280 and $135 \mathrm{~T} / \mathrm{m}^{2}$, compressive strength was between 1.0465 and 183.8 $\mathrm{MPa}$, tensile strength was between -5.2625 and $0.0122 \mathrm{MPa}$, the rock mass strength was between 24.5244 and $220.351 \mathrm{MPa}$, and the large of deformation modulus was between 1.73 and $86.68 \mathrm{GPa}$.

\section{References}

Barber, A.J., Crow, M.J. and Milsom, J.S. (2005) Sumatra: Geology, Resources and Tectonic
Evolution. Geological Society Memoir, No. 31.

Bieniawski, Z.T. (1989) Engineering Rock Mass Classification, Mining and Mineral Resources Research Institute, Pennsylvania State University.

Cheng, Y.M. and Lau, C.K. (2008) Slope Stability Analysis and Stabilization: New Methods and Insight. Routledge. London \& New York.

Giani, G.P. (1992) Rock Slope Stability Analysis, A.A. Balkema Publishers, Rotterdam, Netherlands.

Goodman, R.E. (1989) Introduction to Rock Mechanics. 2nd Edition, John Wiley \& Sons, Canada.

Hoek, E. (1994) Strength of Rock and Rock Masses, News J ISRM 2 (2):4-16.

Hoek, E. (2007) Practical Rock Engineering, Notes, Evert Hoek Consulting Engineer Inc., Canada.

Hoek, E., Carranza-Torres, C. and Corkum, B. (2002) Hoek-Brown Failure Criterion-2002 Edition, Proc. NARMS-TAC Conf., Toronto, Vol. 1, p. 267-273.

Irvani (2013) Rock Mass Quality Evaluation at The Nuclear Power Plant Site Using Rock Mass Rating and Geological Strength Index Methods, in Bangka Barat Regency, Bangka Belitung Archipelago Province. Master Thesis, Gadjah Mada University, Yogyakarta.

Irvani., Wilopo, W., dan Karnawati, D. (2013) Evaluasi Kualitas Massa Batuan Pada Lokasi Tapak PLTN Menggunakan Metode Geological Strength Index, di Kabupaten Bangka Barat, Propinsi Kepulauan Bangka Belitung. Proceeding Seminar Nasional, Teknik Geologi, Universitas Gadjah Mada, Yogyakarta.

IS 12070 (1987) Indian standard code of practice for design and construction of shallow foundations on rocks. New Delhi: Bureau of Indian Standards.

Kilic, A. and Teymen, A. (2008) Determination of Mechanical Properties of Rocks Using Simple Methods, Bull Eng Geol Env., Vol. 67, p. 237-244.

Mangga, A.S. dan Djamal, B. (1994) Peta Geologi Lembar Bangka Utara, Sumatra, Pusat 


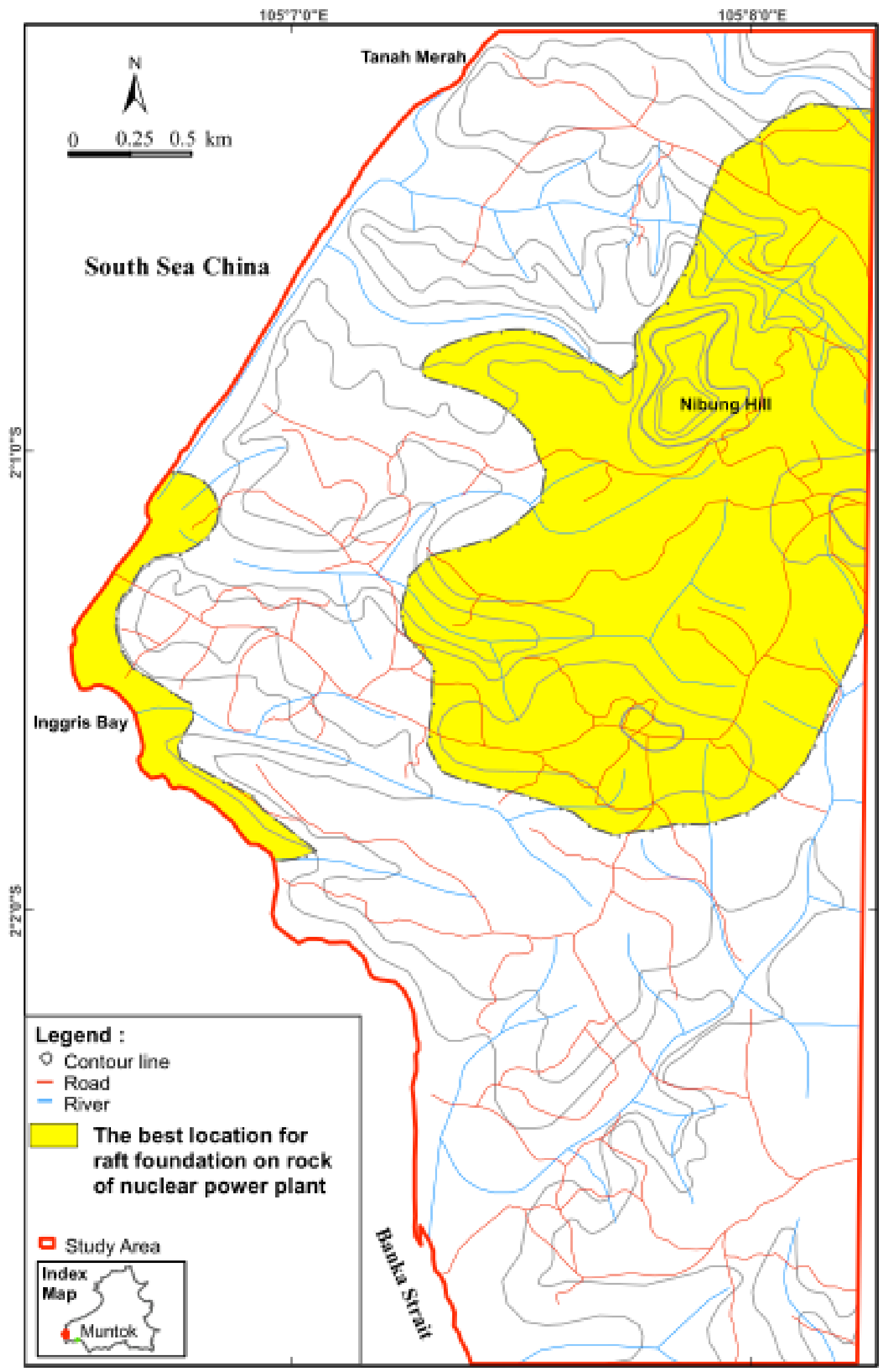

Figure 6: Suitability map for nuclear power plant site. 
Penelitian dan Pengembangan Geologi, Bandung.

Margono, U., Supandjono, R.J.B. dan Partoyo, E. (1995) Peta Geologi Lembar Bangka Selatan, Sumatra. Pusat Penelitian dan Pengembangan Geologi, Bandung.

Palmstrom, A. (1995) RMi - A Rock Mass Characterization System for Rock Engineering Purposes. Thesis (PhD), Oslo University, Norwegia.

Singh, B. and Goel, R.K. (2011) Engineering Rock Mass Classification: Tunneling, Foundation, and Landslides, ButterworthHeinemann, Elsevier Inc., USA, 2011.
Van Bemmelen, R.W. (1970) The Geology of Indonesia, General Geology Volume I A. Martinus Nighoff, The Hague, Netherland.

Van Gorsel, J.T. (2012) Sundaland: Bibliography of The Geology of Indonesia and Surrounding Areas, Edition 4.1., Bibliography of Indonesian Geology.

Wyllie, D.C. (1999) Foundations on Rock, 2nd Edition, E \& FN Spon, London, 1999.

Wyllie, D.C. and Mah, C.W. (2004) Rock Slope Engineering. Civil and Mining Engineering, 4th Edition, Spon Press, New York. 